\title{
EVALUATION OF SELECTED INDICATORS POINTING AT THE CURRENT CONDITION AND IMPORTANCE OF AGRICULTURAL LAND PROTECTION IN SLOVAKIA
}

\author{
HODNOTENIE VYBRANÝCH UKAZOVATELOV \\ POUKAZUJÚCICH NA SÚČASNÝ STAV \\ A DÔLEŽITOSŤ OCHRANY POL'NOHOSPODÁRSKEJ PÔDY \\ NA SLOVENSKU
}

Zina MACHNIČOVÁ*

\section{Introduction}

Soil as one of the basic components of the environment is also a necessary condition for ensuring the quality of life requirements of individuals, but also society. The issue of its protection is dealt by several scientists, authors but also by the institutions of the European Union or the representatives of the government in Slovakia themselves ${ }^{(1)}$. From the perspective of the European Commission, soil has generally been defined as the top layer of the earth's crust made up of minerals, organic matter or living organisms ${ }^{(2)}$. Many authors agree that

Palšová, 2020

European Commission, 2016

\section{Abstract (EN)}

Agricultural land is currently protected by many subjects and institutions. The characteristics of the soil in terms of its functions and importance for individuals or society from perspectives of several scientific disciplines is dealt with by several authors. The aim of the paper is to point out the current state and importance of the agricultural land protection in Slovakia in connection with the threats that affect its quantity and overall quality. The indicators as the area of agricultural land and the structure of the land fund, the evolution of agricultural land withdrawals for non-agricultural purposes and the current state or structure of legislation and institutions in the field of agricultural land protection in Slovakia were evaluated. The paper pointed out the important role of agricultural land in the country, as its area, especially with the majority of arable land and permanent grasslands, represents the majority of the total area of Slovakia. For several years, however, the volume of agricultural land has been steadily declining. This phenomenon is partly caused by the agricultural land withdrawals, which have now managed to stabilize at an average of $1000 \mathrm{ha}$ of withdrawn land per year. In Slovakia, there is currently a large number of legislative acts regulating the protection and agricultural land withdrawals, as well as a wide range of state and non-state institutions that operate in the field of agricultural land protection. The effectiveness of the implementation of legislation and the effectiveness of mutual cooperation of institutions seems questionable focusing on the current state of the land fund, which leads to the need to expand research on these aspects. important factors in characterizing the soil are the functions it performs:

- ecological functions: the soil protects the environment from contamination of groundwater and the food chain precisely by its filtration, buffering and transformation capacities. It also represents a gene reservation or so-called biodiversity base with more organisms than other terrestrial habitats. Last but not least, it produces biomass, food, renewable energy and other components necessary for the existence of life as such;

- non-ecological functions: soil represents the basis for all human activities (housing, industry, waste storage, etc.) and is also a source of raw materials needed for economic

\section{Abstrakt (SK)}

Polnohospodárska pôda je v súčasnosti predmetom ochrany mnohých inštitúcií. Charakteristikou pôdy z hladiska jej funkcií a dôležitosti pre jednotlivcov aj spoločnost' sa $z$ hladiska pohladov viacerých vedných disciplín zaoberajú viacerí autori. Cielom príspevku je poukázat' na súčasný stav a dôležitost' ochrany polnohospodárskej pôdy na Slovensku v súvislosti s hrozbami, ktoré ovplyvňujú jej objem a celkovú kvalitu. Hodnotenými ukazovatel'mi boli najmä výmera polnohospodárskej pôdy a štruktúra pôdneho fondu, vývoj záberov polnnohospodárskej pôdy na nepolnohospodárske účely a súčasný stav a štruktúra legislatívnej úpravy či inštitúcií na úseku ochrany polnnohospodárskej pôdy na Slovensku. Príspevok tak poukázal na významnú úlohu polnohospodárskej pôdy v krajine, nakolko jej výmera najmä v zastúpení ornej pôdy a trvalých trávnatých porastov predstavuje väčšinu celkovej plochy Slovenska. Už niekolko rokov však objem polnohospodárskej pôdy nepretržite klesá. Tento jav je čiastočne zapričinený aj zábermi polnnohospodárskej pôdy, ktoré sa síce $v$ súčasnosti podarilo stabilizovat' na úrovni v priemere 1000 ha vyňatej pôdy za rok. Na Slovensku v súčasnosti existuje pomerne velké množstvo legislatívnych aktov, ktorými je ochrana a samotné zábery polnohospodárskej pôdy upravená a tiež široká škála štátnych i neštátnych inštitúcií, ktoré na úseku ochrany pol'nohospodárskej pôdy pôsobia. Efektívnost' výkonu legislatívy a efektívnost' vzájomnej spolupráce inštitúcí sú však vzhladom na súčasný stav pôdneho fondu otázne, čo vedie k potrebe rozšírenia výskumu v oblasti týchto aspektov.

Slovak University of Agriculture in Nitra, Slovakia 
development (minerals, clay, sand, gravel, etc.). It also represents a cultural and geogenic heritage for the country (3), (4), (5), (6), (7).

Agricultural land in Slovakia was defined by Act No. 220/2004 Coll. on the protection and use of agricultural land and amending certain laws such as "productively potential land registered in the real estate cadastre such as arable land, hops, vineyards, orchards, gardens and permanent grassland". ${ }^{(8)}$

However, the views and approaches of individual subjects on agricultural land are different. While by ecologists it is considered as irreplaceable natural resource, partly independent of human, which at the same time cannot represent a tradable commodity, from the point of view of scientific disciplines such as economy, soil is a common tradable commodity available on the market. For environmentalists it is an initiative to protect it ${ }^{(9)}$.

Currently, EU countries, including Slovakia, are struggling with the problem of agricultural land degradation, mainly due to human activity ${ }^{(10)}$. Therefore, the European Commission has identified several areas of agricultural land protection in relation to the biggest threats affecting its quality (erosion, contamination, loss of organic matter, loss of biodiversity, compaction, salinisation, landslides and impermeable land cover) ${ }^{(2)}$.

In Slovakia, in the field of agricultural soil protection, we recognize mainly legislative (standards), economic (pollution charges, financial support, etc.) and voluntary (environmental education, soil protection strategies, etc.) instruments ${ }^{(11)}$.

Aware of the threat associated with agricultural land decline, the European Parliament has identified the determining factors in the emergence of this problem in the EU, which are mostly huge agricultural land withdrawals for non-agricultural purposes, mostly caused by the complicated land ownership, cheap acquisition price of agricultural land, and malfunctioning legislation or institutional system of executive institutions ${ }^{(12)}$. As land becomes a commercial medium and a motivation for political problems, economic and power gains and self-realization, the institutional system often fails, and land management becomes one of the most corrupt sectors of public administration ${ }^{(13)}$.

\footnotetext{
(3) Tóth, Montanarella, Rusco, 2008

(4) Kefeli, Blum, 2010

(5) Karis, Jettou, 2013

(6) Margottini, 2013

(7) Efe, Ozturk, 2014

(8) Act No 220/2004 Coll. on the protection and agricultural land use

(9) Turanský, 2017

(10) Schwarcz et al., 2016

(11) Enviroportál, 2017

(12) Borras et al., 2016

(13) Burns, Dalrymple, 2018
}

\section{Keywords (EN)}

agricultural land, agricultural land withdrawals, agricultural land protection, agricultural land legislation, Slovakia

\section{Objective and Methodology}

In accordance with the growing need for environmental protection, the paper aims through selected indicators to point out the importance of the protection of agricultural land in Slovakia as an irreplaceable component of the environment.

In relation to the possibility of disturbance or loss of quality and volume of agricultural land, with regard to the availability of resources the following were analysed:

- composition and evolution of the land fund in Slovakia during the observed period,

- evolution of agricultural land withdrawal in Slovakia during the observed period,

- current structure of legislation and bodies operating in the field of agricultural land protection in Slovakia.

Secondary research sources consisted mainly of scientific contributions or publications of domestic and foreign scientists, legislative acts, reports of bodies and institutions of the European Union and Slovakia, and data from databases and statistical surveys of the Statistical Office of the Slovak Republic.

From the methodological point of view, the methods of content analysis and text extraction were used. The approach of abstraction of theoretical issues from secondary sources was used, formulated into scientific assumptions, which were subsequently accepted or rejected through the analysis of relevant empirical data concerning Slovakia. These were processed and presented through graphic representations, on the basis of which interpretations were subsequently formulated.

\section{Results and Discussion}

\subsection{Current Status of Agricultural Land in Slovakia}

Agricultural land of various quality represents the majority (49\%) of the total area of Slovakia (Figure 1). As a result, Slovakia can be considered primarily a rural country with an important role of the agricultural sector and agricultural land in terms of productive as well as non-productive activities within the economy ${ }^{(14)}$. However, since 1993 we have observed a constant declining trend in terms of the total area of agricultural land ${ }^{(15)}$. On the contrary, the area of forest land is growing, which in 2019 represented $41 \%$ of the total area of Slovakia ${ }^{(16)}$.

Agricultural land in accordance with Decree No. 461/2009 Coll. Office of Geodesy, Cartography and Cadastre of the Slovak Republic, which implements the Act of the National Council of the Slovak Republic No. 162/1995 Coll. on the Real Estate Cadastre and on the Registration of Ownership and Other

\footnotetext{
(14) Palšová et al., 2019

(15) Enviroportál, 2020

(16) Enviroportál, 2019
}

Klúčové slová (SK)

polnohospodárska pôda, zábery polnohospodárskej pôdy, ochrana polnohospodárskej pôdy, legislatíva polnohospodárskej pôdy, Slovensko 
Figure 1: The share of individual types of land in the total area of Slovakia in 2019
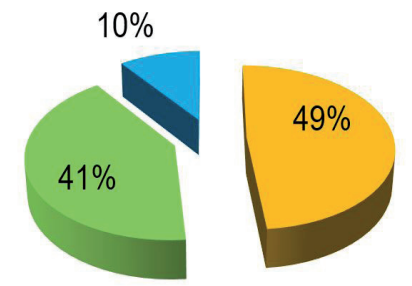

\section{- Forest land}

\section{Non agricultural and non forest land}

Source: own processing according to the Electronic Land Service Yearbook 2019

Rights to Real Estate (Cadastral Act) as amended, was divided into arable land, hops, vineyards, gardens, orchards and permanent grassland ${ }^{(17)}$. Figure 2 shows that arable land (59\%) and permanent grassland (36\%) account for the largest share of agricultural land.

Figure 2: The structure of agricultural land fund in ha in Slovakia in 2019

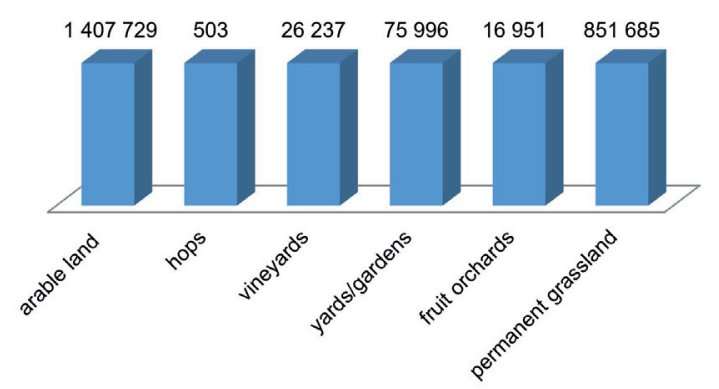

Source: own processing according to the Electronic Land Service Yearbook 2019

According to the analyst of the Slovak Farmer's Cooperative Eva Sadovská, the situation in connection with the decline of agricultural land in Slovakia is alarming.

In the last 15 years, the land fund has been reduced by almost $15 \%$, which represents one sixth of its total area. Most acreage is reduced from arable land, pastures and meadows, while one of the key reasons is considered to be the fragmented land structure in Slovakia, as a result of which the land becomes the subject of interest of speculative entities with non-agricultural intentions ${ }^{(18)}$.

\subsection{Agricultural Land Withdrawals in Slovakia}

In Slovakia, Act No. 220/2014 Coll. on the protection and use of agricultural land allows, under certain conditions, the socalled agricultural land withdrawals for non-agricultural pur-

(17) Decree No 461/2009 Coll by Office of Geodesy, Cartography and Cadastre of the Slovak Republic, which implements the Act of the National Council of the Slovak Republic No 162/1995 Coll on the Real Estate Cadastre and on the Registration of Ownership and Other Rights to Real Estate

(18) Slovak Press Agency, 2017 poses $^{(8)}$. Agricultural land withdrawals are an understandable phenomenon given the growing urbanization and growing population in certain areas. For the need of the quality of the human life, it is therefore necessary to build new settlements, industrial facilities and infrastructure in these areas. The problem, however, is that the current legislation in connection with the fragmented ownership and land structure provides too many opportunities for various speculative machinations in this area, as a result of which agricultural land withdrawals are constantly increasing, which cause negative impacts on the environment. Therefore, many authors discuss the need for more specific legal regulation of this act ${ }^{(1),(12),(19),(20)}$.

According to Figure 3, the most intensive occupations of agricultural land for non - agricultural purposes in Slovakia were realized in 2009 - 2010. In the following years, with an average area of agricultural land withdrawn of 1000 ha, a fairly stable trend with smaller deviations was observed until 2019. The most common reasons for agricultural land withdrawals were housing and industry ${ }^{(12)}$, with the greatest extent of land with high-quality ${ }^{(18)}$. In the last updated period in 2019, a total of 913.95 ha of agricultural land was withdrawn for non-agricultural purposes, with a total increase of 62 ha of land. The differences between the increases and decreases of agricultural land are huge, as a result of which the current trend of the land fund is declining.

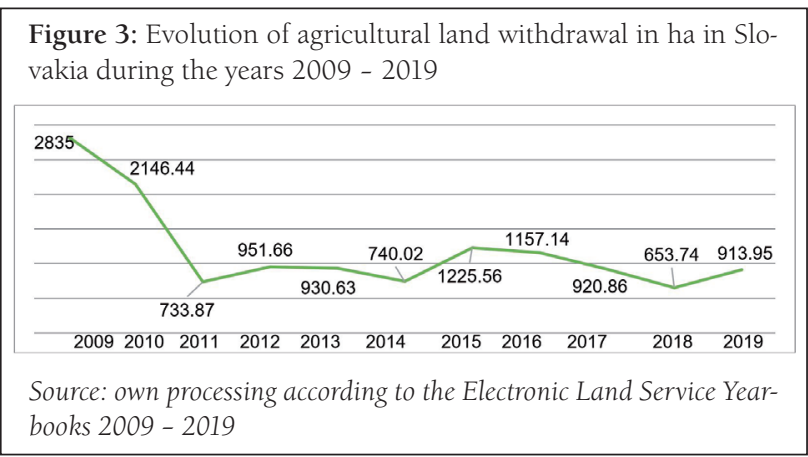

\subsection{Current Structure of Legislation and Bodies Operating in the Field of Agricultural Land Protection in Slovakia}

In particular, one of the most important instruments for the land protection is the legislation. Table 1 shows a comparison of legislation in the field of agricultural land within the EU and Slovakia. The basic document of the EU is the European Soil Charter, which defines the importance of soil for humans and the basic regulation of its protection. Next are Revised European Charter for the Protection and Sustainable Management of Soil and Recommendation of the Council of Europe No. R (92) 8 on soil protection, which emphasize in particular the importance of research as one of the key elements and tools of soil protection. The Common Agricultural Policy (CAP) is considered a ground-breaking document as a partnership between agri-

(19) Melišková, 2018
(20) Blaas et al., 2010 
Table 1: Comparison of legislation in the field of agricultural land protection between the EU and Slovakia

\begin{tabular}{|c|c|}
\hline European Union & Slovakia \\
\hline European Soil Charter & Constitution of SR, art. 44, 45 \\
\hline $\begin{array}{l}\text { Revised European Charter for the Protection and } \\
\text { Sustainable Management of Soil }\end{array}$ & Act No. 17/1992 Coll. on the environment \\
\hline $\begin{array}{l}\text { Recommendation of the Council of Europe No. R } \\
\text { (92) } 8 \text { on soil protection }\end{array}$ & Act No. 220/2004 Coll. on the protection and agricultural land use \\
\hline Common Agricultural Policy: & $\begin{array}{l}\text { Act No. } 203 / 2009 \text { Coll. amending Act No } 188 / 2003 \text { Coll. on the application of sew- } \\
\text { age sludge and bottom sediments to the soil }\end{array}$ \\
\hline EU regulation 1307/2013 & $\begin{array}{l}\text { Act No. } 140 / 2014 \text { Coll. on the acquisition of ownership of agricultural land and on } \\
\text { the amendment of certain laws }\end{array}$ \\
\hline EU regulation 1308/2013 & Act No. $277 / 2017$ Coll. amending Act No 136/2000 Coll. on the fertilizers \\
\hline EU regulation 1305/2013 & $\begin{array}{l}\text { Act No. 119/2019 amending the Act of the Slovak National Council No 330/1991 } \\
\text { Coll. on the land adjustment, land ownership arrangement, land offices, land fund } \\
\text { and land communities }\end{array}$ \\
\hline EU regulation 1306/2013 & $\begin{array}{l}\text { Act No. 356/2019 Coll. amending Act No 543/2002 Coll. on the nature and land- } \\
\text { scape protection }\end{array}$ \\
\hline
\end{tabular}

Source: own processing, 2021

culture and society. In particular, it aims to support farmers in accordance with the conditions of soil protection or overall environmental sustainability.

As part of its operation, the following legal acts were adopted:

- rules for direct payments to farmers (EU regulation 1307/2013);

- a common organisation of the markets in agricultural products (EU regulation 1308/2013);

- support for rural development (EU regulation 1305/2013);

- financing, management and monitoring of the common agricultural policy (EU regulation 1306/2013).

In Slovakia, soil protection is also partially regulated in the highest legal act - the Constitution, specifically in Articles 44 and 45. The soil as a component of the environment is regulated by Act No. 17/1992 Coll. on the environment. Following acts are considered to be key in the field of agricultural land use and protection: Act No. 220/2004 Coll. on the protection and agricultural land use, Act No. 140/2014 Coll. on the acquisition of ownership of agricultural land and on the amendment of certain laws and Act No. 119/2019 amending the Act of the Slovak National Council No. 330/1991 Coll. on the land adjustment, land ownership arrangement, land offices, land fund and land communities.

Agricultural land as a component of the environment, a nonrenewable natural resource or a tool for landscaping and a key element of agricultural development is mentioned in a number of other legal acts, within the EU, for example in Directive No. 2008/98/EC on waste and No. 91/676/EEC on nitrates. In Slovakia for example in Act No 277/2017 Coll. amending Act No 136/2000 Coll. on the fertilizers and Act No 356/2019 Coll. amending Act No 543/2002 Coll. on the nature and landscape protection, etc.

In the field of agricultural land protection, a wide range of institutions operate in Slovakia, holding many functions (Fig. 4). The central authority authorized to issue generally laws, acts and regulations in connection with soil protection is the Ministry of Agriculture and Rural Development (MARD). The Institute of Agricultural Policy is a part of it and at the same time an analytical department in the field of agricultural land. Following bodies are the district offices of the regions, which process information on agricultural land losses for MARD within its territory and works closely with the district offices, which decide on applications for change of land type, agricultural land withdrawals, discuss possible offenses and sanction them ${ }^{(8)}$.

Protective bodies work closely with the supervising bodies, which are the Land Service and the Central Agricultural Inspection and Testing Institute. The Land Service carries out professional supervision and monitors agricultural land in terms of its quality, biodiversity and other functions, then processes this information together with the recommendations in the framework of the agricultural land informational database. It is also responsible for updating the map of rated soil ecological units. The Central Agricultural Inspection and Testing Institute realizes official and state inspections in order of which it takes and analyses soil samples ${ }^{(8)}$.

The Slovak Land Fund is a legal entity established by Act No. 330/1991 Coll. on land adjustment, land ownership arrangements, land offices, land fund and land communities, according to which it is mostly responsible for the management of state-owned agricultural real estate and disposes of land of unknown owners ${ }^{(21)}$

The Agricultural Paying Agency is a state administration body established in accordance with Act No. 473/2003 Coll. on the Agricultural Paying Agency, on the support of entrepreneurship in agriculture and on the amendment of certain laws as amended, which is authorized to provide support and subsidies in the field of agriculture and rural development on the basis of MARD accreditation in accordance with the relevant legal acts ${ }^{(22)}$.

Research and data publication in the field of agriculture and quality of agricultural land in Slovakia is covered by many

(21) Act No 119/2019 amending the Act of the Slovak National Council No 330/1991 Coll. on the land adjustment, land ownership arrangement, land offices, land fund and land communities

(22) Act No 473/2003 Coll on the Agricultural Paying Agency, on the support of business in agriculture and on the amendment 
Figure 4: State administration bodies in the field of agricultural land protection in Slovakia

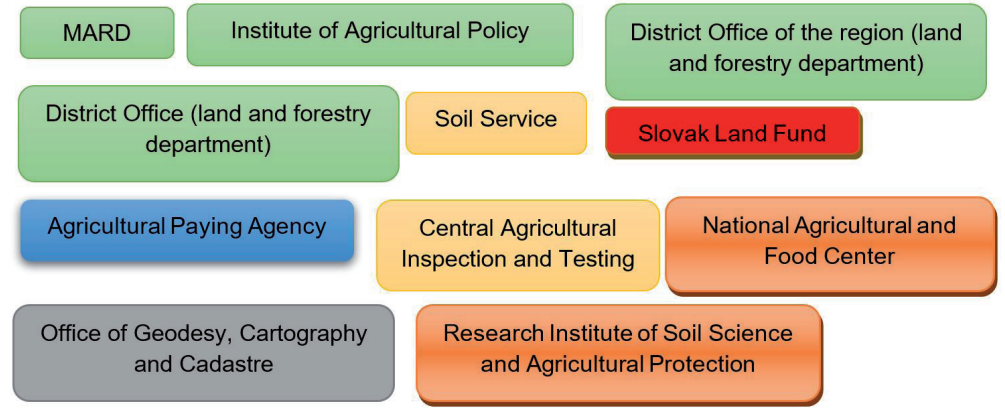

\section{Note: $\square$ protective bodies owners \\ financial bodies

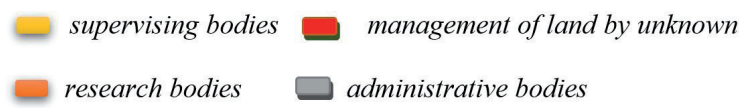

Note: protective bodies supervising bodies management of land by unknown owners financial bodies research bodies administrative bodies Source: own processing, 2021

state and non-state institutions, the most important state institutions include the National Agricultural and Food Centre, while in the field of agricultural land protection the research is realized mostly by Research Institute of Soil Science and Agricultural Protection ${ }^{(23)}$.

The function of offices of Geodesy, Cartography and Cadastre created in accordance with the Act No. 162/1995 Coll. On the Real Estate Cadastre and registration of ownership and other rights to real estate is primary to register data about the real estate data and rights to them. This information is available to the public in the appropriate form and extent through their own informational portal ${ }^{(24)}$.

In addition to state bodies and institutions in Slovakia, a number of non-state or private organizations, institutions, associations or unions representing the interests of its members in the field of agriculture or the protection of agricultural land itself are being established.

One of the most important is the Slovak Chamber of Agriculture and Food, which is characterized as a non-state, public and self-governing institution. Its members, whose interests in relation to state authorities are represented and protected, are individuals and legal entities carrying out business activities, especially in the field of agriculture and food. It covers many unions or associations such as the Association of Agribusiness Entrepreneurs of Slovakia, the Association of Cereal Growers, the Association of Agricultural Cooperatives and Trading Companies, etc.

Considering that the Slovak Chamber of Agriculture and Food is the largest institution representing the interests of entrepreneurs in the field of agriculture, mutual cooperation between the chamber and the relevant state authorities is key for the correct setting of legislative instruments or national strategies.

At present, however, the Slovak Chamber of Agriculture and Food, through statements in the media, is increasingly expressing its dissatisfaction with communication, especially with MARD, and vice versa, MARD considers this criticism to

(23) Ministry of Education, Science, Research and Sport, 2021

(24) Act No. 162/1995 Coll. On the Real Estate Cadastre and registration of ownership and other rights to real estate be unfounded. Conflicts arise in particular in connection with the preparation of the national strategic plan for the Common Agricultural Policy for the period 2021-2027, which represents the key tool for agricultural development and soil protection ${ }^{(25)}$.

\section{Conclusion}

The protection of agricultural land is one of the current but more difficult topics to grasp worldwide. In the European Union, but also in Slovakia, it is gaining more and more attention due to the growing need for food self-sufficiency. The aim of the paper was therefore to point out through selected indicators on the importance of protection and the current state of agricultural land in Slovakia as an irreplaceable component of the environment and the quality of human life. In particular, indicators as the structure of the land fund, the evolution of agricultural land coverage and, last but not least, the structure of legislation and state bodies in the field of agricultural land protection were identified.

The research showed that although agricultural land currently accounts for the majority of the total area of Slovakia, due to its declining share with negative predictions for the future, it is necessary to adopt more effective legislative and non-legislative regulations and instruments in order to protect it.

As part of the evolution of the land fund in Slovakia, monitored mainly by the rate of agricultural land withdrawals, the research pointed to a reduced trend in agricultural land withdrawal over the last 9 years, but the difference between increases and decreases in agricultural land remains disproportionate and alarming.

The legislative regulation of agricultural land is regulated in many legal acts, one of the most important in the EU is the European Soil Charter, while in Slovakia it is mainly Act No. 220/2004 Coll. on the protection and agricultural land use, which, among other, regulates the conditions of agricultural land withdrawals for non-agricultural purposes. The Common Agricultural Policy concluded by the EU with the Member States to promote sustainable agriculture and rural develop-

(25) polnoinfo.sk 
ment is considered a ground-breaking instrument in order to support the agriculture and agricultural land protection.

A significant observation appears to be a large number of state as well as non-state bodies and institutions operating in the field of agricultural land protection. These cover many functions such as protection, control, funding, research or information provision, etc.

Based on the results, it is necessary to summarize that although the protection of agricultural land in Slovakia is covered by a sufficient number of legislative acts and bodies in the field of its protection, due to its declining share, several questions and suggestions for further research arise.

The paper provided several suggestions for further research, as it points out the need to examine in depth the potential causes threatening the quality and size of agricultural land in Slovakia, such as land fragmentation, complicated structure of ownership or increasingly common existence of so-called. "speculative purchases" of agricultural land. In accordance to the sufficient number of legislative acts adopted and the wide range of bodies or institutions operating in the field of agricultural land protection, but its steadily declining share, the key question of efficiency arises, both in the adoption and implementation of legislation, but also in mutual and effective cooperation of the stated bodies and institutions. Given the current state of the land fund, as well as the arguments of many authors, it is clear that the current legislation and the effectiveness of institutions in the field of agricultural land protection in Slovakia does not work ideally. Nevertheless, it is necessary to realize wider research in order to find out whether and how to change of the legislation or the functioning of these institutions will affect the evolution and quality of the land fund in the future. It is important to examine whether they can defend not only their interests, but also accept and subsequently implement decisions beneficial not only for most of them, but for a wide range of the community defending the interests of agricultural land protection in Slovakia.

\section{References}

1. BLAAS, G. et al. 2010. Pôda a polnohospodárstvo úvahy o budúcnosti. [online]. [cit. 2021-03-20]. Available online: < https://www.mpsr.sk/resources/documents/3404.pdf>.

2. BORRAS, S. M.; SEUFERT, P.; BACKES, S.; FYFE, D.; HERRE, R., MICHELE, L.; MILLS, E. N. Land grabbing and human rights: The involvement of European corporate and financial entities in land grabbing outside the European Union. 2016. [online]. [cit. 2021-06-23]. Available online: <https://repub.eur.nl/pub/93661/>.

3. BURNS, T.; DALRYMPLE, K. Conceptual framework for governance in land administration. 2018. [online]. [cit. 2021-06-23]. Available online: <https://www.fig.net/ resources/monthly_articles/2008/august_2008/burns_ dalrymple_august_2008.pdf>.

4. Decree No 461/2009 Coll by Office of Geodesy, Cartography and Cadastre of the Slovak Republic, which implements the Act of the National Council of the Slovak Republic No 162/1995 Coll on the Real Estate Cadastre and on the Registration of Ownership and Other Rights to Real Estate.

5. EFE, R.; OZTURK, M. 2014. Environment and Ecology in the Mediterranean Region II. Newcastle upon Tyne: Cambridge Scholars Publishing, 399 p. ISBN 978-1-44385538-9.

6. ENVIROPORTÁL. 2017. Informačný portál rezortu MŽP SR. [online]. [cit. 2021-04-13]. <https://www.enviroportal.sk/environmentalne-temy/starostlivost-o-zp >

7. ENVIROPORTÁL. 2019. Vývoj plôch lesných pozemkov. [online]. [cit. 2021-04-13]. <https://www.enviroportal. sk/indicator/detail?id=701>.

8. ENVIROPORTÁL. 2020. Štruktúra využívania polnohospodárskej pôdy. [online]. [cit. 2021-04-13]. <https://www.enviroportal.sk/indicator/detail?id=601>.

9. European Commission. 2016. Soil. [online]. [cit. 202104-13]. Available online:<http://ec.europa.eu/environment/soil/index_en.htm>.

10. KARIS, A.; JETTOU, D. 2013. Land Use and Land Management, Practices in Environmental Perspective. Morocco: INTOSAI WGEA, 79 p. ISBN 978-9949-9061-9-2.

11. KeFELI, V; BLUM, W. E. H. 2010. Mechanisms of Landscape Rehabilitation and Sustainability. Belgicko: Bentham Science Publishers, 124 p. ISBN 978-1-60805168-7.

12. Ministry of Education, Science, Research and Sport of Slovak Republic. Register verejných výskumných inštitúcíi. [online]. [cit. 2021-04-16]. Available online:< https://regvvi.cvtisr.sk/>.

13. MARGOTTINI, C. 2013. On the Protection of Cultural Heritages from Landslides. In Landslide Science and Practice. Berlin: Springer, 415-426 p. ISBN 978-3-64231318-9.

14. MELIŠKOVÁ, I. 2018. Usage of Agricultural Land for Non-Agricultural Purposes in Slovakia. [online]. [cit. 2021-04-18]. Available online:〈https://www.sciendo. com/article/10.2478/eual-2018-0002>.

15. Palšová et al. 2019. Modelling Development, Territorial and Legislative Factors Impacting the Changes in Use of Agricultural Land in Slovakia. Sustainability, 2019, 11.14: 3893. [online]. [cit. 202104-19]. Available online:<https://www.mdpi.com/20711050/11/14/3893>.

16. PALŠOVÁ, L. 2020. Agricultural lands - fields of conflicts. 1. Edition. Warsaw University of life sciences, Warsaw, Poland, 2020. p. 111, ISBN 978-83-7583-980-7.

17. Polnoinfo.sk. Články na tému SPPK. [online]. [cit. 202104-19]. Available online: <https://polnoinfo.sk/tema/ sppk/>.

18. SCHWARCZ, P. et al. 2016. European Agricultural and Environmental Policy. Nitra: Slovenská polnohospodárska univerzita v Nitre, 253 p. ISBN 978-80-552-1576-1.

19. SLOVAK PRESS AGENCY. 2017. Výmera využitej polnohospodárskej pôdy na Slovensku za 15 rokov klesla o šestinu. [online]. [cit. 2021-04-19]. Available online: <https://openiazoch.zoznam.sk/cl/182023/Vymera-vyuzitej-polnohospodarskej-pody-na-Slovensku-za-rokovklesla-o-sestinu>

20. TÓTH, G.; MONTANARELlA, L.; RUSCO, E. 2008. Threats to Soil Quality in Europe. Luxemburg: Office for 
Official Publications of the European Communities, 150 p. ISBN 978-92-79-09529-0.

21. TURANSKÝ, V. 2017. Pôda nie je tovar. Trh sa bude regulovat. In Hospodárske noviny. [online]. [cit. 202104-15]. Available online: <http://hnporadna.hnonline. sk/clanky/939049-poda-nie-je-tovar-trh-sa-bude-regulovat>.

22. Act No. 162/1995 Coll. On the Real Estate Cadastre and registration of ownership and other rights to real estate

23. Act No 473/2003 Coll on the Agricultural Paying Agency, on the support of business in agriculture and on the amendment.

24. Act No 220/2004 Coll on the protection and agricultural land use.

25. Act No 119/2019 amending the Act of the Slovak National Council No 330/1991 Coll on the land adjustment, land ownership arrangement, land offices, land fund and land communities.

26. Geodesy, Cartography and Cadastre Authority of the Slovak Republic. Electronic Land Service Yearbook in SR 2009-2019. [online]. [cit. 2021-04-19]. Available online: <http://www.skgeodesy.sk/sk/ugkk/kataster-nehnutelnosti/sumarne-udaje-katastra-podnom-fonde/>.

\section{Contact address/ Kontaktná adresa}

Ing. Zina Machničová

Department of Law,

Faculty of European Studies and Regional Development,

Slovak University of Agriculture in Nitra, Tr. A. Hlinku 2, 94976 Nitra,

e-mail:xmachnicova@uniag.sk 